of trying to find out whether the well-established sunspot periodicities, other than that of eleven years, exists or not in prominences. He limits himself to periodicities up to eleven years in this communication, and studies them by the periodogram method as before. The data used are those published by the Italian observers, and deal with all prominences more than $30^{\prime \prime}$ in height recorded since 1871 . A brief summary of his conclusions is as follows. The prominence periodogram is very similar to that of spots tor the same time interval. Between two years and eleven years there are no periodicities present in prominences which can be proved to be absent from sun-spots and vice versa. The eleven-year period is the predominant feature of the prominence periodogram, and its maxima occur about one year later than in sun-spots. The maxima of its first subperiod, 5.56 years, are not delayed in prominences. Periods between seven and eight years of considerable intensity in prominences have been shown to be present also in spots, but they are not permanently active. As regards shorter periods, that of thirteen months in prominences is not present in spots, and one of $8 \frac{1}{4}$ months in spots is stated to disappear for a time and then reappear. In December last (NATURe, vol. xcii., No. 230I, p. 4II) reference was made to Prof. A. A. Michelson's determinations of sun-spot periodicities by the harmonic analyser, but he could not find any periodicity other than that of eleven years.

\section{THE TEACHING OF ANTHROPOLOGY AT THE UNIVERSITIES.}

$\triangle$ JOINT committee of the Royal Anthropological 4 Institute and Section $H$ of the British Association, of which Sir Richard Temple is chairman, has had under consideration the steps desirable to give practical effect to the conclusions resulting from the discussion, which took place at the meeting of the British Association at Birmingham last September, on the practical application of anthropological teaching in universities. It will be remembered that it was held at Birmingham that increased facilities should be offered at our universities for training those who, in after life as officials, business men, missionaries, and the like, will be brought into close contact with the peoples of the Empire, whose civilisation is alien to our own. After careful consideration, the joint committee is of opinion that such facilities can best be offered by the collaboration of the Royal Anthropological Institute, the British Association, and the universities, with the support and the cooperation of the Government, the Foreign Office, the India Office, the Colonial Office, and the Civil Service Commissioners, and that it would be well for the organisation to take the form of encouraging the existing schools of anthropology in the universities and the formation of such schools, where none exist, with their indispensable adjuncts of laboratories, libraries, and museums.

In furtherance of the scheme thus elaborated a conference was summoned by the joint committee at the Drapers' Hall, by courtesy of the Master and Wardens of the Drapers' Company, on Thursday, February I9, under the chairmanship of the Earl of Selborne, K.G. Letters supporting the proposals of the conference were received from, among others, the Colonial Secretary, Lord Cromer, Sir Richard Martin, Sir Robert Blair, Sir George Grierson, Sir Joseph Larmor, M.P., Sir John Rhys, Sir Ernest Trevelyan, and the Right Honourable Ameer Ali. An encouraging feature was the presence of an official representative of the Colonial Office.

No. 23 I3, VOL. 927
The following resolution was moved by Sir Henry Craik, M.P., seconded by Sir Everard im Thurn (Royal Geographical Society), and carried unanimously :- "That this conference approves the findings and views of the joint committee, and is of the opinion that, in the highest interests of the Empire, it is necessary so to extend and complete the organisation of the teaching of anthropology at the universities of Great Britain, that those who are about to spend their lives in the East, or in parts of the Empire inhabited by non-European races, shall at the outset of their career possess or have the opportunity of acquiring a sound and accurate knowledge of the habits, customs, social and religious ideas and ideals of the Eastern and nonEuropean races subject to his Majesty the KingEmperor."

A second resolution, moved by Sir Hercules Read (British Museum), and seconded by Dr. T. H. Warren (Oxford University), was as follows:- "That this conference hereby authorises the chairman and members of the joint committee of the British Association for the Advancement of Science and the Royal Anthropological Institute, to represent to the Prime Minister, the Right Hon. Herbert Henry Asquith, K.C., M.P., the opinions of this conference as set forth in the preceding resolution, and to move him to appoint an Interdepartmental Committee for the purpose of advising as to the form in which the sympathy and support of his Majesty's Government can be best expressed." The resolution was carried unanimously.

All the speakers to the resolutions strongly endorsed the findings of the joint committee, and pointed out how seriously handicapped were young men in every walk of life, who went abroad without any anthropological training, amongst alien peoples, and it was only by the painful process of committing mistakes that they were enabled to get an insight into the habits and customs of those with whom they came into daily contact. The Hon. J. G. Jenkins (London Chamber of Commerce) bore testimony to the wastage of millions of pounds sterling in trade owing to this fact, as the mistakes constantly made by the untrained men, who were sent out by commercial firms, were made at the expense of the firms; in the case also of the untrained missionary, he stated that during his first years abroad ground was lost and good influence retarded until he began to get a knowledge of the people, finally, from his own experience as a Minister in the Government of South Australia, he laid strong emphasis on the necessity for State aid in the anthropological training of the youth of the Empire.

As Prof. Arthur Keith pointed out, the Royal Anthropological Institute has spent more than thirty years in collecting information, so that the knowledge is available, but it is the dissemination of this knowledge that is necessary, and to achieve this object the institute had been trying for the last twenty years to induce the Imperial Government to help by means of financial support.

Dr. J. G. Frazer (British Science Guild) mentioned that it was largely due to the lack of anthropological training that the recent outbreak occurred in Somaliland, and this is not the first occasion on which loss of life and money has been attributed to the same cause.

In the interests of the Empire it is earnestly to to be hoped that Dr. Warren will prove a true prophet and official support will be given in a matter of such vital importance, and that a scientific system of anthropological training will be the outcome of the conference, and thereby crown with success the labours of the joint committee and of its indefatigable secretary. 